\title{
青森県小学生の身体活動量が体型および 体力・運動能力に及ぼす影響
}

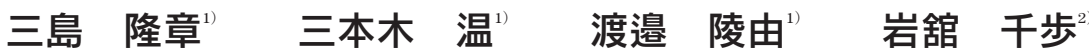

\section{Effects of physical activity on the body type, physical fitness and motor ability in elementary school students living in Aomori prefecture}

\author{
Takaaki Mishima ${ }^{1}$, Yutaka Sambongi', Takayuki Watanabe ${ }^{1}$ and Chiho Iwadate
}

\begin{abstract}
This study aimed to clarify the effects of physical activity on the body type, physical fitness and motor ability in elementary school students living in Aomori prefecture. Subjects were 448 elementary school students (226 boys, 222 girls) living in Aomori Prefecture. As morphometry, we measured height and weight, and calculated the obesity index as an indicator of body type. Physical fitness and motor ability tests were grip strength, $20 \mathrm{~m}$ dash, side steps, standing long jump and the speed of the tennis ball throw. Physical activity was evaluated by pedometer, worn around the waist for 7 days. We examined the relationship between physical activity and body type. As a result, there was no significant correlation between physical activity and obesity index. In order to remove the influence of development of physical fitness and motor ability, $\mathrm{T}$ score of physical fitness and motor ability were calculated based on the age at the time of measurement by polynomial. Correlation analysis between physical activity and T score of physical fitness and motor ability showed a positive correlation between physical activity on weekdays and standing long jump in boys. A positive correlation was shown for the relationship between physical activity in weekdays and side steps and tennis ball-throwing velocity, physical activity in weekends and $20 \mathrm{~m}$ dash, side steps and tennis ball-throwing velocity, respectively, in girls. These results suggest that physical activity does not influence on body type in elementary school students who live in cold district. In addition, it is shown a weak correlation between physical activity and physical fitness and motor ability.
\end{abstract}

Key words : cold district, body type, physical activity, physical fitness and motor ability 寒冷地，体型，身体活動量，体力·運動能力

\section{I 緒 言}

近年，先進諸国において大きく取り上げられて いる健康問題のひとつに, 子どもの肥満があげら れている. 日本においても例外ではなく, 特に本
州の最北端に位置する青森県では, 肥満傾向児出 現率が他の都道府県と比較して著しく高い. 平成 21 年度の青森県の児童・生徒の肥満傾向児出現率 は, 男女とも 6 歳〜 17 歳までのいずれの年齢段階 においても全国平均を上回っており，なかには全

1）八戸学院大学人間健康学部

2) 株式会社楽天野球団

${ }^{1}$ Faculty of Human Health Science, Hachinohe Gakuin University

${ }^{2}$ RAKUTEN BASEBALL, INC 
国平均の 2 倍近くの值を示す年齢段階まである (青森県教育庁スポーツ健康課, 2011)。青森県の 成人において, BMI が 25.0 以上の肥満が男女と も平均で $30 \%$ を超えていること, また脳血管疾 患, 悪性新生物, 心疾患および糖尿病といった生 活習慣病による超過死亡が青森県の平均寿命を押 し下げていることからも（青森県健康福祉部保健 衛生課, 2007), 青森県の子どもに対し肥満増加を 抑制する対策を講じることは急務である.

子どもに肥満が増加した要因のひとつに, 高度 経済成長に伴う身体活動量の低下の関与が指摘さ れている. 子どもにおける歩数調査は 1970 年代 から現在に至るまで行われており, 1970 年代では 27,500 歩/日であったものが，現在では 12,000 歩/日から $15,000 /$ 日歩程度にまで減少している ことが明らかにされている（小林・小澤, 2007). 12 歳の男女 5,500 人において加速時計を用いた 身体活動量と体脂肪率との間に負の相関があるこ とが報告されており（Ness et al., 2007），身体活 動量と体型との間に密接な関連性があることが分 かる．また，子どもの身体活動量に対して気候が 及ぼす影響も指摘されており，冬季では身体活動 量が低下することが明らかとなっている（塙, 2011). 体重の季節変動について検討した結果で は, 体重は秋から冬に増加し, 日照時間よりも気 温の影響を受けることが示唆されている（小林ほ か, 2004). よって, 他の地域と比べ冬期間が長く 積雪が多い青森県で生活する子どもは，身体活動 量が他の地域と比べて低いことがひとつの要因と なり, 肥満傾向児出現率が高くなると推測できる が, 筆者の知る限りこれまで詳細な検討が行われ たことはない.

身体活動量は, 体型のみならず体力・運動能力 に影響を及ぼすことが指摘されている，児童を対 象に体力テストの結果から高得点群と低得点群よ り多いことが報告されている（塙, 2011)．1日の 歩数と新体力テストの成績との関連性について調 ベた結果から, 新体力テストで $\mathrm{C}$ の総合評価を得 るには男子で少なくとも 16,000 歩/日, 女子で 12,000 歩/日，Bの総合評価を得るには男子で少 なくとも 17,000 歩/日, 女子で 13,000 歩/日必要 であることが推測されている（笹山ほか, 2009）. 青森県の児童の体力・運動能力は全国平均と比べ
低いことが指摘されていることから（青森県教育 庁スポーツ健康課, 2011), 身体活動量と体力・運 動能力の関連性を明らかにすることによって，体 力・運動能力を改善する方法として身体活動量増 加の有効性を提言できると考えられる。

そこで本研究では, 青森県の小学生を対象に身 体活動量, 体型および体力・運動能力を測定し, 身体活動量が体型，体力・運動能力に及ぼす影響 について明らかにすることを目的とした。

\section{II 方 法}

\section{1. 被験者および調査時期}

被験者は, 青森県内の小学校に在籍する 1 年生 から 5 年生の男子児童 226 名 (1 年生; 51 名, 2 年 生; 35 名, 3 年生; 49 名, 4 年生; 36 名, 5 年生; 55 名), 女子児童 222 名（1 年生； 48 名，2 年生； 41 名, 3 年生; 49 名, 4 年生 ; 38 名, 5 年生; 46 名）で, 調査時期は平成 22 年 10 月下旬から 11 月 上旬であった，実験を開始するにあたり, 被験者, 被験者の保護者および小学校の教員に対して本研 究の目的，方法および実験の安全性を十分に説明 し，実験参加に対する同意書を得た。なお，本研 究は八戸大学・八戸短期大学研究倫理委員会の倫 理審査を受け，承認を得たうえで実施された（No. 10-03).

\section{2. 身体活動量の測定}

身体活動量の測定には，一軸加速度計（オムロ ン社製 HJ203）を使用した。測定を実施するにあ たり，児童および教員に対して，使用方法や使用 にあたっての注意点を十分に説明した。また，保 護者に対しては，使用方法および注意点について まとめた文書を事前に配布した．被験者には睡眠 時と入浴や水泳など装着できない場合を除いて, 一軸加速度計をズボンのポケットに入れ付属のク リップで落ちないように固定させた状態で, 休日 を含めた連続する 7 日間にわったて装着するよう に指示をした.

\section{3. 体型の測定}

各被験者の身長は身長計（エーアンド・デイ社

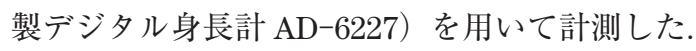


体重は, 体内脂肪計 (タニタ社製夕ニ夕体組成計 インナースキャン BC-521）を用いて測定した. 体型を示す肥満度は, 平成 21 年度児童生徒の健 康・体力（青森県教育庁スポーツ健康課, 2011） の性別・年齢別・身長別の平均体重を用い, 次の 式より算出した.

肥満度 $(\%)=($ 実測体重 - 標準体重 $) /$ 標準体重 $\times 100$

この肥満度を基に, 肥満度が $+20 \%$ 未満の者を 標準 (Normal；N）群, 肥満度が+20\%以上の者を 肥満 (Fatty； F) 群に分類した。

\section{4. 体力・運動能力の測定}

本研究では, 握力, $20 \mathrm{~m}$ 走, 立ち幅跳び, 反復 横跳びおよびテニスボール投球速度を用いて体 力・運動能力の測定を行った.いずれの測定も体 育館で実施し, 各測定項目の実施方法は次の通り であった. $20 \mathrm{~m}$ 走は, 光電管 (Brower 社製スピー ドトラップ）を用いてタイムを計測した。 スター トラインおよびゴールラインに光電管を設置し, 選手はスタートラインにつま先を揃え, 任意の夕 イミングでスタンディングスタートから全力疾走 を行わせた. 100 分の 1 秒まで計測し，2 回測定 を行い良い方の記録を採用した。一般的には，テ ニスボールやソフトボールをできるだけ遠くに投 げる，すなわち投距離を投能力と定義する場合が 多い. 本研究では冬期にも投能力を測定すること を予定しており，青森県において冬期に屋外で投 距離を測定することは積雪や寒さのため困難だと 予想される。そこで本研究では，投能力を評価す る方法としてテニスボール投球速度を測定した。 なお，投球時の初速度と投距離との間に有意な正 の相関が認められていることから（小林ほか, 2012), 投球速度が速い方ほど投能力が優れてい ることを示している．硬式テニスボールを直径 2 $\mathrm{m}$ のサークルの中から, $10 \mathrm{~m}$ 先の高さ $1 \mathrm{~m}$ に設 置した標的に向かってオーバーハンドで投げるよ うに指示した。この時, 被験者の斜め後方に設置 したスピードガン (ユピテル社製 MST-1) を用い, 投球ボールの初速度 $(\mathrm{km} / \mathrm{h})$ を $1 \mathrm{~km} / \mathrm{h}$ 単位まで 計測した。試技は 2 回行い, 良い方の記録を採用
した，握力，立ち幅跳びおよび反復横跳びは，文 部科学省が平成 11 年から採用している新体力テ ストの測定方法に従って行った.

\section{5. 解析の手続き}

(1)身体活動量, 体型および体力・運動能力につ いて, 1 年生から 5 年生まで学年毎に性別に算出 したものをさらに $\mathrm{N}$ 群, $\mathrm{F}$ 群に分け, 統計值を算 出する.

(2)身体活動量と体型との関係について, Pearson の相関係数を用いて検定する.

(3)年齢に対する体力・運動能力の回帰分析を行 い, 1 次から 3 次までの回帰多項式を算出し, 妥 当な次数の回帰多項式を決定する.

(4)妥当な次数の回帰多項式を用いて体力・運動 能力の $\mathrm{T}$ スコアを算出し, 身体活動量と体力・運 動能力との関係について, Pearsonの相関係数を 用いて検定する.

\section{6. 回帰多項式の次数の妥当性について}

回帰多項式の次数の妥当性については, 田中ほ か（2009）の方法を採用した。回帰多項式は，一 般的には 2 変量における回帰分析による回帰直線 が適用される。しかし，2 変量における回帰分析 でも 1 次の関係より 2 次以上の関係がより妥当と 判断される場合もある。そのような場合には 2 次, 3 次, 4 次等の近似多項式が適用されることが ある。したがって，本研究における年齢に対する 体力・運動能力の回帰多項式における次数決定に ついては, 残差平方和の検討によって妥当な次数 が判断される. また, 残差平方和の検討と同時に 赤池情報量基準（AIC）を適用して次数の妥当性 を確認した。 AICの算出式は次の通りである.

$$
A I C=n \times \log \frac{\sigma}{n}+2 \times(\mathrm{k}+2)+(\log 2 \pi+1)
$$

(但し, $\sigma$ は偏差平方和, $\mathrm{n}$ はデー夕数, $\mathrm{k}$ は説 明変数の数)

\section{7. 統計処理}

統計量は, 平均土標準偏差で示した。身体活動 量と体型および体力・運動能力の関係は, Pearsonの相関係数を用いて評価した，有意水準は 
Table 1 Statistics of physical activity and physique classified by fatty-normal degree judgment of obesity in boys and girls.

Boys

\begin{tabular}{|c|c|c|c|c|c|c|c|}
\hline \multirow[b]{2}{*}{ Grade } & \multirow[b]{2}{*}{ Group } & \multirow[b]{2}{*}{$\mathrm{N}$} & \multirow[b]{2}{*}{$\%$} & \multicolumn{2}{|c|}{ Physical activity } & \multicolumn{2}{|c|}{ Physique } \\
\hline & & & & $\begin{array}{l}\text { Weekdays } \\
\text { (counts/day) }\end{array}$ & $\begin{array}{l}\text { Weekend days } \\
\text { (counts/day) }\end{array}$ & $\begin{array}{l}\text { Height } \\
(\mathrm{cm})\end{array}$ & $\begin{array}{l}\text { Weight } \\
(\mathrm{kg})\end{array}$ \\
\hline \multirow{2}{*}{1} & $\mathrm{~N}$ & 44 & $86.3 \%$ & $12,780 \pm 2,845$ & $7,563 \pm 3,660$ & $120.7 \pm 5.7$ & $23.2 \pm 3.5$ \\
\hline & $\mathrm{F}$ & 7 & $13.7 \%$ & $12,349 \pm 4,366$ & $6,737 \pm 5,499$ & $125.1 \pm 3.4$ & $35.3 \pm 6.6$ \\
\hline \multirow{2}{*}{2} & $\mathrm{~N}$ & 28 & $80.0 \%$ & $12,118 \pm 2,422$ & $7,029 \pm 3,997$ & $126.1 \pm 5.7$ & $26.4 \pm 4.4$ \\
\hline & $\mathrm{F}$ & 7 & $20.0 \%$ & $15,206 \pm 6,752$ & $7,084 \pm 6,416$ & $126.6 \pm 6.9$ & $34.9 \pm 5.5$ \\
\hline \multirow{2}{*}{3} & $N$ & 40 & $81.6 \%$ & $16,511 \pm 6,902$ & $10,102 \pm 9,477$ & $130.8 \pm 6.9$ & $28.6 \pm 5.3$ \\
\hline & $\mathrm{F}$ & 9 & $18.4 \%$ & $15,140 \pm 2,538$ & $8,270 \pm 3,276$ & $134.8 \pm 6.9$ & $42.2 \pm 6.7$ \\
\hline \multirow{2}{*}{4} & $N$ & 33 & $91.7 \%$ & $15,348 \pm 3,762$ & $9,349 \pm 3,963$ & $133.8 \pm 5.3$ & $30.1 \pm 4.7$ \\
\hline & $\mathrm{F}$ & 3 & $8.3 \%$ & $16.998 \pm 1,951$ & $9,769 \pm 3,875$ & $130.0 \pm 2.5$ & $35.0 \pm 3.7$ \\
\hline \multirow{2}{*}{5} & $\mathrm{~N}$ & 39 & $70.9 \%$ & $14,733 \pm 3,554$ & $9,696 \pm 4,310$ & $142.9 \pm 5.9$ & $35.5 \pm 5.4$ \\
\hline & $\mathrm{F}$ & 16 & $29.1 \%$ & $15,450 \pm 5,065$ & $10,426 \pm 5,233$ & $143.3 \pm 7.0$ & $52.4 \pm 12.4$ \\
\hline
\end{tabular}

Girls

\begin{tabular}{|c|c|c|c|c|c|c|c|}
\hline \multirow[b]{2}{*}{ Grade } & \multirow[b]{2}{*}{ Group } & \multirow[b]{2}{*}{$\mathrm{N}$} & \multirow[b]{2}{*}{$\%$} & \multicolumn{2}{|c|}{ Physical activity } & \multicolumn{2}{|c|}{ Physique } \\
\hline & & & & $\begin{array}{l}\text { Weekdays } \\
\text { (counts/day) }\end{array}$ & $\begin{array}{l}\text { Weekend days } \\
\text { (counts/day) }\end{array}$ & $\begin{array}{l}\text { Height } \\
(\mathrm{cm})\end{array}$ & $\begin{array}{l}\text { Weight } \\
(\mathrm{kg})\end{array}$ \\
\hline \multirow{2}{*}{1} & $\mathrm{~N}$ & 43 & $89.6 \%$ & $11,129 \pm 2,582$ & $7,785 \pm 4,183$ & $119.4 \pm 5.2$ & $22.4 \pm 3.4$ \\
\hline & $\mathrm{F}$ & 5 & $10.4 \%$ & $13,094 \pm 1,907$ & $10,219 \pm 2,306$ & $123.8 \pm 4.9$ & $32.2 \pm 4.1$ \\
\hline \multirow{2}{*}{2} & $N$ & 37 & $90.2 \%$ & $10,823 \pm 2,612$ & $8,164 \pm 2,528$ & $125.2 \pm 5.8$ & $25.0 \pm 3.8$ \\
\hline & $\mathrm{F}$ & 4 & $9.8 \%$ & $12,220 \pm 1,876$ & $7,349 \pm 2,094$ & $127.1 \pm 5.9$ & $35.7 \pm 5.7$ \\
\hline \multirow{2}{*}{3} & $\mathrm{~N}$ & 46 & $93.9 \%$ & $11,443 \pm 2,596$ & $8,531 \pm 3,126$ & $131.7 \pm 7.2$ & $28.7 \pm 5.0$ \\
\hline & $\mathrm{F}$ & 3 & $6.1 \%$ & $13,755 \pm 1,489$ & $6,601 \pm 4,604$ & $134.2 \pm 6.2$ & $37.6 \pm 5.1$ \\
\hline \multirow{2}{*}{4} & $\mathrm{~N}$ & 34 & $89.5 \%$ & $11,943 \pm 2,450$ & $8,012 \pm 3,086$ & $137.9 \pm 6.7$ & $32.6 \pm 5.3$ \\
\hline & $F$ & 4 & $10.5 \%$ & $14,207 \pm 1,125$ & $7,332 \pm 1,276$ & $144.7 \pm 5.9$ & $49.2 \pm 6.0$ \\
\hline \multirow{2}{*}{5} & $N$ & 43 & $93.5 \%$ & $11,389 \pm 3,407$ & $7,673 \pm 3,973$ & $145.4 \pm 5.5$ & $36.6 \pm 4.8$ \\
\hline & $\mathrm{F}$ & 3 & $6.5 \%$ & $12,799 \pm 3,987$ & $10,832 \pm 3,400$ & $137.9 \pm 9.5$ & $44.4 \pm 5.7$ \\
\hline
\end{tabular}

Values are means $\pm S D$. $N$ : normal group, $F$ : fatty group.

$5 \%$ 未満とした。 なお, $\mathrm{F}$ 群と $\mathrm{N}$ 群の差の検討は 本研究の目的ではないため, 検定は行わなかった.

\section{III 結 果}

\section{1. 被験者の基本特性ついて}

Table 1 は被験者を性別・年歯別・身長別の平 均体重を用い $\mathrm{N}$ 群, $\mathrm{F}$ 群に分類したときの身体活 動量および体格, Table 2 は体力・運動能力の結 果を示している. 本研究の被験者における肥満傾 向児出現率は, 男子の 1 年生で $13.7 \%, 2$ 年生 $20.0 \%, 3$ 年生で $18.4 \%, 4$ 年生で $8.3 \%, 5$ 年生 で $29.1 \%$ であった。全国規模での調査結果では
男子の肥満傾向児出現率が 6 歳で $3.75 \%, 7$ 歳で $5.18 \%, 8$ 歳で $6.70 \%, 9$ 歳で $8.39 \%, 10$ 歳で $9.42 \%, 11$ 歳で $9.46 \%$ であることから(文部科学 省, 2012), 肥満傾向児出現率が高い集団を対象に 調査を実施したことを示している。一方，女子に おける肥満傾向児出現率は, 本研究の結果では 1 年生で $10.4 \%, 2$ 年生 $9.8 \%, 3$ 年生で $6.1 \%, 4$ 年生で $10.5 \%, 5$ 年生で $6.5 \%$ であり，全国規模 での調查結果である 6 歳で $3.93 \%, 7$ 歳で $4.86 \%, 8$ 歳で $5.94 \%, 9$ 歳で $6.82 \%, 10$ 歳で $7.71 \%, 11$ 歳で $8.12 \%$ (文部科学省, 2012) と比 較しても大きな差異はないことが分かる。した がって, 女子は男子とは異なり, 一般的な体型を 
Table 2 Statistics of physical fitness and motor ability classified by fatty-normal degree judgment of obesity in boys and girls

Boys

\begin{tabular}{|c|c|c|c|c|c|c|c|c|}
\hline \multirow[b]{2}{*}{ Grade } & \multirow[b]{2}{*}{ Group } & \multirow[b]{2}{*}{$\mathrm{N}$} & \multirow[b]{2}{*}{$\%$} & \multicolumn{5}{|c|}{ Physical fitness and motor ability } \\
\hline & & & & $\begin{array}{c}\text { Grip strength } \\
(\mathrm{kg})\end{array}$ & $\begin{array}{c}20 \text { m dash } \\
\text { (sec) }\end{array}$ & $\begin{array}{l}\text { Side step } \\
\text { (times) }\end{array}$ & $\begin{array}{l}\text { Standing } \\
\text { long jump } \\
\quad(\mathrm{cm})\end{array}$ & $\begin{array}{c}\text { Tennis-ball } \\
\text { throwing } \\
\text { velocity } \\
(\mathrm{km} / \mathrm{h})\end{array}$ \\
\hline \multirow{2}{*}{1} & $N$ & 44 & $86.3 \%$ & $10.0 \pm 2.8$ & $4.77 \pm 0.38$ & $28.2 \pm 4.7$ & $117.3 \pm 15.9$ & $41.2 \pm 8.2$ \\
\hline & $\mathrm{F}$ & 7 & $13.7 \%$ & $10.6 \pm 1.6$ & $5.01 \pm 0.40$ & $28.4 \pm 2.2$ & $101.1 \pm 19.2$ & $40.9 \pm 8.4$ \\
\hline \multirow{2}{*}{2} & $\mathrm{~N}$ & 28 & $80.0 \%$ & $10.5 \pm 2.4$ & $4.58 \pm 0.32$ & $31.1 \pm 4.0$ & $121.7 \pm 12.0$ & $46.5 \pm 11.2$ \\
\hline & $\mathrm{F}$ & 7 & $20.0 \%$ & $11.0 \pm 3.3$ & $4.85 \pm 0.31$ & $29.9 \pm 3.4$ & $109.4 \pm 11.4$ & $48.4 \pm 9.6$ \\
\hline \multirow{2}{*}{3} & $N$ & 40 & $81.6 \%$ & $13.6 \pm 3.2$ & $4.33 \pm 0.28$ & $35.4 \pm 6.3$ & $144.5 \pm 16.9$ & $51.2 \pm 8.7$ \\
\hline & $\mathrm{F}$ & 9 & $18.4 \%$ & $15.8 \pm 1.9$ & $4.50 \pm 0.12$ & $36.0 \pm 3.9$ & $124.4 \pm 7.4$ & $53.6 \pm 8.4$ \\
\hline \multirow{2}{*}{4} & $N$ & 33 & $91.7 \%$ & $15.2 \pm 2.9$ & $4.14 \pm 0.28$ & $42.9 \pm 4.4$ & $153.1 \pm 18.0$ & $59.5 \pm 13.3$ \\
\hline & $F$ & 3 & $8.3 \%$ & $15.3 \pm 0.6$ & $4.24 \pm 0.06$ & $39.0 \pm 4.4$ & $144.0 \pm 14.5$ & $46.0 \pm 1.0$ \\
\hline \multirow{2}{*}{5} & $N$ & 39 & $70.9 \%$ & $16.8 \pm 4.0$ & $3.97 \pm 0.22$ & $43.8 \pm 6.0$ & $159.3 \pm 18.0$ & $71.1 \pm 14.7$ \\
\hline & $\mathrm{F}$ & 16 & $29.1 \%$ & $19.4 \pm 5.9$ & $4.37 \pm 0.36$ & $38.9 \pm 4.0$ & $139.9 \pm 16.8$ & $62.7 \pm 12.6$ \\
\hline
\end{tabular}

Girls

\begin{tabular}{|c|c|c|c|c|c|c|c|c|}
\hline \multirow[b]{2}{*}{ Grade } & \multirow[b]{2}{*}{ Group } & \multirow[b]{2}{*}{$\mathrm{N}$} & \multirow[b]{2}{*}{$\%$} & \multicolumn{5}{|c|}{ Physical fitness and motor ability } \\
\hline & & & & $\begin{array}{c}\text { Grip strength } \\
(\mathrm{kg})\end{array}$ & $\begin{array}{c}20 \text { m dash } \\
\text { (sec) }\end{array}$ & $\begin{array}{l}\text { Side step } \\
\text { (times) }\end{array}$ & $\begin{array}{l}\text { Standing } \\
\text { long jump } \\
\quad(\mathrm{cm})\end{array}$ & $\begin{array}{c}\text { Tennis-ball } \\
\text { throwing } \\
\text { velocity } \\
(\mathrm{km} / \mathrm{h})\end{array}$ \\
\hline \multirow{2}{*}{1} & $\mathrm{~N}$ & 43 & $89.6 \%$ & $8.6 \pm 2.2$ & $4.90 \pm 0.35$ & $28.0 \pm 3.7$ & $106.2 \pm 14.5$ & $33.3 \pm 3.4$ \\
\hline & $\mathrm{F}$ & 5 & $10.4 \%$ & $10.2 \pm 1.5$ & $4.86 \pm 0.16$ & $25.8 \pm 1.9$ & $99.6 \pm 8.7$ & $35.0 \pm 4.8$ \\
\hline \multirow{2}{*}{2} & $N$ & 37 & $90.2 \%$ & $10.2 \pm 2.3$ & $4.75 \pm 0.34$ & $28.5 \pm 4.3$ & $112.1 \pm 14.8$ & $34.2 \pm 3.5$ \\
\hline & $\mathrm{F}$ & 4 & $9.8 \%$ & $13.0 \pm 3.2$ & $5.03 \pm 0.35$ & $28.5 \pm 3.9$ & $97.8 \pm 18.3$ & $38.3 \pm 6.2$ \\
\hline \multirow{2}{*}{3} & $\mathrm{~N}$ & 46 & $93.9 \%$ & $12.3 \pm 3.0$ & $4.48 \pm 0.29$ & $33.7 \pm 5.6$ & $128.9 \pm 17.9$ & $37.8 \pm 5.5$ \\
\hline & $\mathrm{F}$ & 3 & $6.1 \%$ & $11.0 \pm 4.4$ & $4.43 \pm 0.18$ & $32.7 \pm 3.5$ & $137.0 \pm 7.0$ & $36.7 \pm 2.5$ \\
\hline \multirow{2}{*}{4} & $N$ & 34 & $89.5 \%$ & $14.9 \pm 3.1$ & $4.19 \pm 0.21$ & $39.7 \pm 4.1$ & $143.8 \pm 16.8$ & $41.2 \pm 9.0$ \\
\hline & $\mathrm{F}$ & 4 & $10.5 \%$ & $20.5 \pm 3.4$ & $4.37 \pm 0.22$ & $37.8 \pm 2.6$ & $130.8 \pm 21.1$ & $50.0 \pm 11.3$ \\
\hline \multirow{2}{*}{5} & $N$ & 43 & $93.5 \%$ & $17.4 \pm 3.0$ & $4.15 \pm 0.27$ & $41.1 \pm 3.9$ & $149.0 \pm 18.6$ & $45.4 \pm 8.5$ \\
\hline & $F$ & 3 & $6.5 \%$ & $19.0 \pm 11.8$ & $5.10 \pm 0.96$ & $30.0 \pm 3.0$ & $119.0 \pm 46.0$ & $37.0 \pm 11.3$ \\
\hline
\end{tabular}

Values are means $\pm S D$. $N$ : normal group, $F$ : fatty group.

有する集団を対象に調査を実施したことを意味す る.

1 日の歩数は，男女ともに体型にかかわらず平 日で約 13,000 歩/日, 休日で約 9,000 歩/日であっ た（Table 1)。2000 年以降，児童を対象に加速度 計または歩数計を用いて検討がなされた 1 日の歩 数をみると, 平日の男子で 11,000 歩〜20,000 歩/ 日程度, 女子で 10,000 歩 17,000 歩/日程度, 休 日の男子で 8,000 歩/日〜 12,000 歩/日程度, 女子 で 6,500 10,000 歩/日程度であることが報告さ
Table 3 Relationship between physical activity and obesity index in boys and girls

\begin{tabular}{cccccc}
\hline & \multicolumn{2}{c}{ Boys } & & \multicolumn{2}{c}{ Girls } \\
\cline { 2 - 3 } \cline { 5 - 5 } & Weekdays $\begin{array}{c}\text { Weekend } \\
\text { days }\end{array}$ & & Weekdays $\begin{array}{c}\text { Weekend } \\
\text { days }\end{array}$ \\
\hline $\begin{array}{c}\text { Obesity } \\
\text { index }\end{array}$ & 0.036 & -0.016 & & 0.053 & -0.081 \\
\hline
\end{tabular}

れている（三井ほか，2009；笹山ほか，2009；海 老原ほか, 2011). 本研究の被験者の歩数と大き 
Table 4 Determination of the degree of polynomial by residual sum of squares and AIC in boys and girls

\begin{tabular}{|c|c|c|c|c|}
\hline Order & $\begin{array}{l}\text { Coefficient } \\
\text { correlation }\end{array}$ & $\begin{array}{l}\text { Residual } \\
\text { sum of } \\
\text { squares }\end{array}$ & AIC & Choise \\
\hline \multicolumn{5}{|l|}{ Boys } \\
\hline \multicolumn{5}{|l|}{ Grip strength } \\
\hline Linear & 0.649 & 2538.809 & 1202.54 & \multirow[t]{3}{*}{$\bigcirc$} \\
\hline Quadratic & 0.650 & 2528.803 & 1203.64 & \\
\hline Cubic & 0.652 & 2519.294 & 1204.78 & \\
\hline \multicolumn{5}{|l|}{$20 \mathrm{~m}$ dash } \\
\hline Linear & 0.653 & 23.708 & 136.95 & \multirow[t]{3}{*}{$\bigcirc$} \\
\hline Quadratic & 0.655 & 23.623 & 138.13 & \\
\hline Cubic & 0.655 & 23.622 & 140.12 & \\
\hline \multicolumn{5}{|l|}{ Side step } \\
\hline Linear & 0.741 & 6171.529 & 1405.06 & \multirow[t]{3}{*}{0} \\
\hline Quadratic & 0.741 & 6168.680 & 1406.96 & \\
\hline Cubic & 0.742 & 6138.325 & 1407.83 & \\
\hline \multicolumn{5}{|c|}{ Standing long jump } \\
\hline Linear & 0.654 & 73300.309 & 1969.27 & \multirow[t]{3}{*}{$\bigcirc$} \\
\hline Quadratic & 0.656 & 72981.078 & 1970.28 & \\
\hline Cubic & 0.657 & 72890.779 & 1972.00 & \\
\hline \multicolumn{5}{|c|}{ Tennis ball-throwing } \\
\hline Linear & 0.655 & 30064.523 & 1766.08 & \multirow{3}{*}{$\bigcirc$} \\
\hline Quadratic & 0.667 & 29200.321 & 1761.43 & \\
\hline Cubic & 0.671 & 28967.099 & 1761.60 & \\
\hline \multicolumn{5}{|l|}{ Girls } \\
\hline \multicolumn{5}{|l|}{ Grip strength } \\
\hline Linear & 0.746 & 1934.084 & 1108.56 & \multirow[t]{3}{*}{$\bigcirc$} \\
\hline Quadratic & 0.748 & 1925.414 & 1109.57 & \\
\hline Cubic & 0.749 & 1917.155 & 1110.63 & \\
\hline \multicolumn{5}{|l|}{$20 \mathrm{~m}$ dash } \\
\hline Linear & 0.644 & 23.320 & 136.58 & \multirow[t]{3}{*}{$\bigcirc$} \\
\hline Quadratic & 0.646 & 23.178 & 137.24 & \\
\hline Cubic & 0.647 & 23.163 & 139.10 & \\
\hline \multicolumn{5}{|l|}{ Side step } \\
\hline Linear & 0.755 & 4480.699 & 1293.39 & \\
\hline Quadratic & 0.756 & 4476.987 & 1295.21 & \\
\hline Cubic & 0.764 & 4339.217 & 1290.33 & $\bigcirc$ \\
\hline \multicolumn{5}{|c|}{ Standing long jump } \\
\hline Linear & 0.694 & 65102.961 & 1882.15 & \multirow[t]{3}{*}{$\bigcirc$} \\
\hline Quadratic & 0.696 & 64809.074 & 1883.16 & \\
\hline Cubic & 0.696 & 64739.098 & 1884.92 & \\
\hline \multicolumn{5}{|c|}{ Tennis ball-throwing } \\
\hline Linear & 0.603 & 7180.538 & 1397.14 & \multirow{3}{*}{$\bigcirc$} \\
\hline Quadratic & 0.614 & 7036.819 & 1394.70 & \\
\hline Cubic & 0.615 & 7027.108 & 1396.39 & \\
\hline
\end{tabular}

AIC : Akaike's information criterion

な差はないことから, 本研究の被験者は調査期間 中において男女ともに一般的な児童の身体活動量 を有していたことを示している.

\section{2. 身体活動量と体型との関連性について}

Table 3 は男女児童の平日および休日の身体活 動量と体型を示す肥満度との間の相関係数を算出 した結果を示している，男女ともに平日の身体活 動量, 休日の身体活動量のいずれも, 肥満度との 
Table 5 Statistics of T-score of physical fitness and motor ability classified by fatty-normal degree judgment of obesity in boys and girls

\begin{tabular}{lcrlcccc} 
& Group & $\mathrm{N}$ & $\begin{array}{c}\text { Grip strength } \\
(\mathrm{kg})\end{array}$ & $\begin{array}{c}20 \mathrm{~m} \text { dash } \\
(\mathrm{sec})\end{array}$ & $\begin{array}{c}\text { Side step } \\
\text { (times) }\end{array}$ & $\begin{array}{c}\text { Standing } \\
\text { long jump } \\
(\mathrm{cm})\end{array}$ & $\begin{array}{c}\text { Tennis-ball } \\
\text { throwing velocity } \\
(\mathrm{km} / \mathrm{h})\end{array}$ \\
\hline \multirow{2}{*}{ Boys } & $\mathrm{N}$ & 186 & $49.1 \pm 9.2$ & $51.8 \pm 9.5$ & $50.8 \pm 10.2$ & $51.7 \pm 9.6$ & $50.4 \pm 10.0$ \\
& $\mathrm{~F}$ & 42 & $54.1 \pm 12.1$ & $43.6 \pm 9.6$ & $46.6 \pm 7.9$ & $42.5 \pm 7.9$ & $48.3 \pm 9.5$ \\
\hline \multirow{2}{*}{ Girls } & $\mathrm{N}$ & 201 & $49.3 \pm 8.9$ & $50.9 \pm 9.1$ & $50.5 \pm 9.8$ & $50.6 \pm 9.4$ & $49.7 \pm 9.3$ \\
& $\mathrm{~F}$ & 19 & $56.8 \pm 16.6$ & $43.8 \pm 16.0$ & $44.3 \pm 10.0$ & $44.2 \pm 13.5$ & $52.8 \pm 15.1$ \\
\hline
\end{tabular}

Values are means $\pm S D$. $N$ : normal group, $F$ : fatty group.

Table 6 Relationship between physical activity and T-sore of physical fitness and motor ability in boys and girls

\begin{tabular}{lrrrrc} 
& Grip strength & 20 m dash & Side step & $\begin{array}{r}\text { Standing } \\
\text { long jump }\end{array}$ & $\begin{array}{c}\text { Tennis-ball } \\
\text { throwing velocity }\end{array}$ \\
\hline $\begin{array}{l}\text { Boys } \\
\text { Weekdays }\end{array}$ & 0.117 & 0.140 & 0.027 & $0.141^{*}$ & 0.109 \\
$\quad \begin{array}{l}\text { Weekend days } \\
\text { Girls }\end{array}$ & 0.051 & 0.025 & 0.017 & -0.001 & -0.054 \\
Weekdays & 0.002 & 0.105 & $0.272^{* * *}$ & 0.110 & $0.147^{*}$ \\
Weekend days & -0.044 & $0.172^{*}$ & $0.202^{* *}$ & 0.114 & $0.201^{* *}$ \\
\hline${ }^{*} P<0.05,{ }^{* *} P<0.01,{ }^{* * *} P<0.001$ & & & &
\end{tabular}

間に有意な相関は認められなかった.

\section{3. 身体活動量と体力・運動能力との関連性に ついて}

体力・運動能力は, 加齢と伴に発達することは 言うまでもない. したがって, 単純に身体活動量 と体力・運動能力の各測定項目の関連性を比較し たならば, 体力・運動能力の発達という要因が加 わるために，正確な関連性を見出すのは困難であ る.そこで, 体力・運動能力において被験者の年 齢による多項式を用いた平均值および標準偏差を 推定し, 推定された平均值と標準偏差值を用いて 体力・運動能力を測定時の年齢に基づいた, 体力・ 運動能力の各測定項目における $\mathrm{T}$ スコアを算出 する．算出された各体力・運動能力の $\mathrm{T}$ スコアと 身体活動量との相関を検討することによって，身 体活動量と体力・運動能力との関連性について明 らかにできる。まず，被験者の測定日年齢に対す る運動能力の回帰分析を行い, 1 次から 3 次まで の回帰多項式を算出し, 妥当な次数の多項式を決 定した．なお，次数の決定には残差平方和および 赤池情報量基準 (AIC) を適用して, 次数の妥当性
を確認した（Table 4). 多項式から得られた回帰 多項式を用い, 被験者毎に測定時の年齢に基づい た体力・運動能力の T スコアを算出し (Table 5), 身体活動量との比較検討を行った（Table 6)。身 体活動量と体力・運動能力の $\mathrm{T}$ スコアとの関係に ついて検討した結果, 男子では平日の歩数と立ち 幅跳びとの間に有意な正の相関があることが認め られた $(\mathrm{r}=0.141 ; \mathrm{P}<0.05)$. 女子では平日の歩 数と反復横跳び（ $\mathrm{r}=0.272 ； \mathrm{P}<0.001 ）$ およびテ ニスボール投球速度 $(\mathrm{r}=0.147 ; \mathrm{P}<0.05)$, 休日 の歩数と $20 \mathrm{~m}$ 走 $(\mathrm{r}=0.172 ; \mathrm{P}<0.05)$, 反復横跳 び $(\mathrm{r}=0.202 ; \mathrm{P}<0.01)$ およびテニスボール投球 速度 $(\mathrm{r}=0.201 ; \mathrm{P}<0.01)$ との間に有意な正の相 関があることが認められた。

\section{IV 考察}

児童·生徒の身体活動量を評価する方法として, 質問紙法や行動観察法, 歩数計法, 心拍法が用い られてきたが, 身体活動量を正確に定量できない といった問題を抱えていることが指摘されている (海老根ほか, 2002). 近年開発された加速度セン 
サーを用いた加速度計法は, 二重標識水法によっ て測定された身体活動量と高い相関を示すことが 報告されているため（海老根ほか, 2002 ; 足立ほ か, 2007), 信頼性についてはすでに確証を得てい る。しかしながら機器が高価であるため, 大規模 集団の身体活動量を同時期に測定することは困難 を伴う。したがって, 本研究では, 比較的安価に 大規模集団を測定できる一軸加速度計を用いて身 体活動量の測定を行った。 なお, 本研究で用いた 一軸加速度計と同じタイプの一軸加速度計の信頼 性についても, 先行研究により信頼性について確 証を得ている (Crouter et al., 2003).

本研究より得られた知見のひとつに，青森県の 児童において身体活動量と体型との間に関連性が 認められなかったことがある，仙台市郊外の農村 地域の小学生高学年児童において, 標準体型群と 肥満体型群の歩数には差がなかったことも踏まえ (糸井ほか, 2003), 青森県の览童において肥満傾 向児出現率が高い要因として, 身体活動量は関与 していない可能性があることを示唆している.

身体活動量と体型との関連性を検討するために は, 身体活動量の変化が体型に及ぼす影響, もし くは体型の変化が身体活動量の変化に及ぼす影響 という双方向からの縦断的な検討が必要とされ る. 134 人の過体重な小学生を介入群, コント ロール群に分け， 6 力月後および 12 力月後の身体 活動量や BMI の変化を調査した結果, 身体活動 量はコントロール群と比較して介入群の方が増加 したが, BMI の変化には差が認められなかったと 報告している（Hughes et al., 2008）。学校におけ る運動介入が体格に及ぼす影響についてメ夕解析 を行った結果, 運動介入が体格に影響を及ぼさな かったことから（Harris et al., 2009）, 子どもにお いて身体活動量の変化が体型に影響を及ぼさない 可能性があることを示唆している。, 一方, 体型が 身体活動量に及ぼす影響についても検討がなされ ている. 202 名の小学生を 7 歳から 4 年間追跡調 査した結果, 7 歳, 8 歳および 9 歳時の身体活動量 と, その後の体脂肪率の変化率との間には関連性 が認められなかったが, 7 歳, 8 歳および 9 歳時の 体脂肪率と後の身体活動量の変化率との間には負 の相関が認められている（Metcalf et al., 2011）. 肥満児童は小学校 3 年生以前まで活発に活動して
いるが, 小学校 4 年生以降になると運動習慣が低 下することでエネルギー摂取量が消費量を上回 り, 肥満が進行するとの報告からも（安部ほか, 2003)，身体活動量の変化が体型に影響を及ぼす のではなく，体型が身体活動量に影響を及ぼす可 能性の方が高いことを示唆している. 農村地帯や 漁村における食生活が肥満に関与しているとの報 告もなされているが（大竹ほか，2011；宇加江ほ か, 2002), 寒冷地における体型変化そのものを誘 起する要因についての議論は, 本論の主旨から逸 れるため控えたい.いずれにしても, 本研究より 得られた結果は, 横断的調査に基ついている. し たがって, 身体活動量の変化が体型に及ぼす影響, もしくは体型の変化が身体活動量の変化に及ぼす 影響について縦断的検討を行うことで, 青森県の 児童における肥満の要因のひとつに, 寒冷な気候 が関与しているか否か確証を得ることができると 考えられる。

本研究の結果より, 男子では平日の歩数と立ち 幅跳び，女子では平日の歩数と反復横跳びおよび テニスボール投球速度, 休日の歩数と $20 \mathrm{~m}$ 走, 反復横跳びおよびテニスボール投球速度との間に 有意な相関があることが認められた（Table 6). 小学校の 5 年生, 6 年生の男女児童において平日 の歩数を新体力テストとの関連性を調べた結果, 男子では握力, $20 \mathrm{~m}$ シャトルラン, $50 \mathrm{~m}$ 走, 立ち 幅跳びおよび総得点, 女子では立ち幅跳びのみ歩 数と有意な相関があることが認められている（戸 田ほか, 2007).小学校 4 年生の男女児童におい て行われた調査においても, 男子では歩数とす心゙ ての測定項目および総得点との間，女子では上体 起し, $20 \mathrm{~m}$ シャトルラン, ソフトボール投げおよ び総得点との間に有意な相関があることが示され

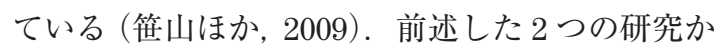
ら，男子では多くの測定項目において歩数との関 連性が認められるが, 女子では男子より関連性が 認められる項目が少ないことが分かる．男女に違 いが生じる理由として，男子の方が女子より身体 活動量が多く分布の幅が広いことが要因となって いると推察されている（戸田ほか，2007；笹山ほ か, 2009). 本研究の結果においても, 1 年生から 5 年生までのいずれの学年においても, 男子の方 が女子よりも身体活動量が多いことが明らかにさ 
れている（Table 1)。それにもかからず男子にお いてほとんどの項目で身体活動量と体力・運動能 力との間に関連性が認められず，女子において多 くの体力・運動能力が身体活動量と関連性がある ことが認められた。ただし，相関係数がもっとも 高いのは, 女子の平日の歩数と反復横跳びの $\mathrm{r}=$ 0.272 であることから, 身体活動量と体力・運動 能力との間には強い関連性があるとは言えない.

この理由として，本研究では測定時の年齢を基に して算出した体力・運動能力の $\mathrm{T}$ スコアと身体活 動量とを比較したことが考えられる。ただし，身 体活動量と体型との関連性についてでも述べた が, 本研究より得られた結果は横断的調査に基づ いている。したがって，身体活動量の変化が体 力・運動能力に影響を及ぼすか, もしくは体力・ 運動能力の変化が身体活動量に影響を及ぼすかを 検討するために, 今後, 縦断的な調査の結果を分 析する必要がある.

\section{$\mathrm{V}$ 総 括}

本研究は，青森県の児童を対象に身体活動量が 体型および体力・運動能力に及ぼす影響を検討す ることを目的として行われた。体格として身長お よび体重, 体力・運動能力として, 握力, $20 \mathrm{~m}$ 走, 立ち幅跳び，反復横跳びおよびテニスボール投球 速度の測定を行った。体型は肥満度を用いて分類 を行い, 肥満度が $20 \%$ 以上の児童を肥満群（F 群)，20\%未満の児童を標準群 ( $\mathrm{N}$ 群) とした。身 体活動量として一軸加速度計を 7 日間装着させ, 身体活動量と体型，体力・運動能力との関連性に ついて分析を行い, 以下の結果を得た。

(1)平日および休日の身体活動量と体型との間 に，男女とも有意な相関は認められなかった。

(2)測定時の年齢から体力・運動能力の $\mathrm{T}$ スコア を算出し，身体活動量との関連性について検討し た結果, 男子では平日の歩数と立ち幅跳びとの間 に有意な相関（ $\mathrm{r}=0.141 ； \mathrm{P}<0.05)$ ，女子では平 日の歩数と反復横跳び $(\mathrm{r}=0.272 ; \mathrm{P}<0.001)$ お よびテニスボール投球速度 $(\mathrm{r}=0.147 ; \mathrm{P}<0.05)$, 休日の歩数と $20 \mathrm{~m}$ 走 $(\mathrm{r}=0.172 ; \mathrm{P}<0.05)$, 反復 横跳び $(\mathrm{r}=0.202 ； \mathrm{P}<0.01)$ およびテニスボール 投球速度 $(r=0.201 ； \mathrm{P}<0.01)$ との間に有意な正
の相関があることが認められた。しかしながら， 相関係数から判断すると，有意な正の相関が認め られた項目のすべてが，ほとんど相関ないから低 い相関の範囲であった。

以上の結果より, 寒冷地に生活する览童におい て，身体活動量は体型に影響を及ぼしていないこ とが示唆された，身体活動量は，特に女子におい て体力・運動能力に影響を及ぼすが，体力・運動 能力に及ぼす影響はさほど大きくない可能性であ ることが示唆された。

\section{謝 辞}

調査資料の収集にあたり御協力を賜りました青森 県教育委員会および小学校関係者の皆様に深謝致し ます。なお, 本研究の一部は, 未来を担う子ども健康 生活推進事業（青森県教育委員会）の委託を受け行わ れたものである.

\section{文献}

安部恵子, 三村寛一, 鉄口宗弘, 勝野眞吾 (2003) 小 学校肥満児童の体力と生活習慣について, 学校保 健研究，45，397-405

足立稳, 笹山健作, 引原有輝, 沖嶋今日太, 水内秀次, 角南良幸，塩見優子，西牟田守，菊永茂司，田中 宏暁，齋藤慎一，吉武裕（2007）小学生の日常生 活における身体活動量の評価 : 二重標識水法と加 速度計による検討，体力科学， 56, 347-356

青森県教育庁スポーツ健康課 (2011) 平成 22 年度児 童生徒の健康・体力

青森県健康福祉部保健衛生課（2007）「健康あ招もり $21 」$ 改訂版

海老原修, 桜井智野風, 木村みかさ, 佐々木玲子, 長 谷川博, 高原和子 (2011) 子どもの日常的歩数の 同定，発育発達研究， 51，92-100

海老根直之, 島田美恵子, 田中宏暁, 西牟田守, 吉武 裕, 齊藤憤一, Jones, P. J. H. (2002) 二重標識水法 を用いた簡易エネルギー消費量推定法の評価一 生活時間調查法, 心拍数法, 加速度計法につい て一, 体力科学, 51，151-164

小林博隆, 小澤治夫（2007）加速度計を内蔵した歩数 計による子どもの歩数トレンドグラム, 東海大学 紀要体育学部，37，35-39

小林正子，遠藤幸子，高野陽（2004）南北 5 地域保育 
所児童における身長・体重の時系列解析による季 節変動の検討，小児保健研究， $63 ， 535-543$

小林育斗, 阿江通良, 宮崎明世, 藤井範久 (2012) 優 れた投能力をもつ小学生の投動作の特徵とその 標準動作, 体育学研究, 57, 613-629

Crouter, S., Schneider, P., Karabulut, M. and Bassett, D. Jr. (2003) Validity of 10 electronic pedometers for measuring steps, distance, and energy cost, Med Sci Sports Exere, 35, 1455-1460

塙佐敏（2011）歩数を基にした子どもの適切な身体活 動量の検討一可変要因（運動習慣, 生活習慣) や 不変要因 (季節) と歩数との関連から一, 発育発 達研究, 54, 1-10

Harris, K.C., Kuramoto, L.K., Schulzer, M. and Retallack, J.E. (2009) Effect of school-based physical activity interventions on body mass index in children : a meta-analysis, CMAJ, 180, 719-726

Hughes, A.R., Stewart, L., Chapple, J., McColl, J.H., Donaldson, M.D., Kelnar, C.J., Zabihollah, M., Ahmed, F. and Reilly, J.J. (2008) Randomized, controlled trial of a best-practice individualized behavioral program for treatment of childhood overweight: Scottish Childhood Overweight Treatment Trial (SCOTT), Pediatrics, 121, e539e546

糸井亜弥, 田中靖人, 木村みさか (2003) 農村地域の 小学生高学年児童における活動量と栄養摂取に 関する調查, 学校保健研究, 45, 454-464

Metcalf, B.S., Hosking, J., Jeffery, A.N., Voss, L.D., Henley, W. and Wilkin, T.J. (2011) Fatness leads to inactivity, but inactivity does not lead to fatness : a longitudinal study in children (EarlyBird 45), Arch Dis Child, 96, 942-947

三井隆弘，茨島朋子，金地美知彦，島岡清（2009）階 上町小学生の身体活動と肥満との関連，科教研 報，24，27-28

文部科学省 (2012) 平成 23 年度学校保健統計調查 Ness, A.R., Leary, S.D., Mattocks, C., Blair, S.N., Reilly, J.J., Wells, J., Ingle, S., Tilling, K., Smith, G.D. and Riddoch, C. (2007) Objectively measured physical activity and fat mass in a large cohort of children, PLoS Med, 4, e97

大竹まり子, 佐久間夕美子, 佐々木晶世, 瀧浪敦, 清 石幸子，森鍵祐子，細谷たき子，小林淳子，叶谷 由佳，大貫義人，佐藤千史（2011）山形県の児童 生徒における体格・体力の検討 I一肥満傾向児の 地域差一, 日本健康医学会雑誌, $20,90-96$

笹山健作, 沖嶋今日太, 水内秀次, 足立稔 (2009) 小 学生の日常生活における身体活動量と体力との 関連性，体力科学， 58，295-304

田中望, 藤井勝紀, 石垣享, $\mathrm{Nho} \mathrm{H}$, Kim $\mathrm{S}-\mathrm{H}$, 花井忠 征（2009）韓国人中学生の身体組成と体力との関 係構図における発育学的検証, 発育発達研究, 41 , $44-57$

戸田粋子, 渡辺丈真, 唐誌陽（2007）高学年児童にお ける日常身体活動量及び体力, 体格との関連, 学 校保健研究, 49, 348-362

宇加江進，吉田雅喜，菅沼隆，伊藤希美（2002）小児 肥満と生活習慣病の現状〜北海道内の小学校に おける調查～，札棍社会保険総合病院医誌， 11 , 5-8

(受付： 2012 年 9 月 3 日, 受理： 2013 年 5 月 23 日)

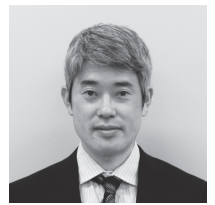

三島 隆章（みしま たかあき）

現職：八戸学院大学人間健康学部准教授
広島大学大学院生物圈科学研究科博士後期単位取得退学. 博士 (学術). 専門は運動生理学, 発育発達学. 現在, 筋疲 労に関する研究の他, ジュニアスポーツ選手を対象とした 体力・運動能力の発達に関する研究にも取り組んでいる. 